\title{
TEACHING THE HERITAGE LANGUAGE AS A FOREIGN LANGUAGE: ON THE QUESTIONS OF BILINGUALISM AND MINORITY LANGUAGE TEACHING IN AUSTRIA
}

\author{
Marta Csire and Johanna Laakso \\ University of Vienna
}

\begin{abstract}
Although Hungarians in Austria are an officially recognised ethnic minority, surprisingly little attention has been given to the specific problems in teaching Hungarian as a heritage language. This paper focuses on the situation of heritage-language students who study Hungarian as part of a university curriculum in Vienna, together with German speakers. These students have learnt colloquial varieties of Hungarian as a spoken language in their families but typically have no formal training in the standard written language. This leads to learners' errors which are often due to lacking language awareness: heritage-language students are unable to analyse their grammatical intuitions. It is also obvious that heritagelanguage students do not profit from traditional second-language teaching methods and material; furthermore, heterogeneous teaching groups rather create than solve problems. These issues, probably critical for an increasing group of multilingual speakers in many countries, call for more differentiated approaches to language planning and educational strategies.
\end{abstract}

Keywords: heritage language, Hungarian, academic learners, language awareness

\section{Introduction}

\subsection{The Hungarian language in Austria}

Hungarians (by language, origin or self-identification) in Austria constitute a fairly large but very heterogeneous group. In addition to the old "autochthonous" minority in the easternmost province of Burgenland, there are diverse immigrant groups from Hungary and other Hungarian-speaking areas. Actually, the Hungarians in Austria - like the Finns in Sweden - belong to a centuries-old pattern of constant migration within the empire. Despite assimila- 
tion, there has been a continuous presence of Hungarianness in Austria.

The Hungarian groups in Austria do not necessarily share a common identity, as their political and ethnopolitical backgrounds and their personal relationship with Austrianness, Hungarianness and the Hungarian nation-state may vary greatly. Nor is there a strong and nationally visible organ or organization which could claim to unite all Hungarians in Austria. True, there are numerous Hungarian organizations and clubs and a "Central Council of Hungarian Organizations in Austria" (cf. Deák [s.a.]), but these have not succeeded in bringing about strong political cooperation or a common minority-political agenda. Most of these organizations and groups work on a local basis, concentrating on cultural activities such as folk dance clubs, and there is no concerted political strategy or reaction to the changing situation of Hungarian-speaking communities in Austria.

According to the census of 2001, there were more than 40,000 Hungarians in Austria (of these, roughly 10,000 in Burgenland), and a little more than a half of them gave Hungarian as their language (or one of their languages) of everyday spoken communication (Umgangssprache). However, according to a study from 2005, more than 90,000 Austrians can speak Hungarian, and most of these probably have a Hungarian ethnic background (Jelentés 2006). Obviously, for many Hungarians in Austria their heritage language does not suffice to identify them as "Hungarians". There are probably large fringe groups not shown in any statistics: children of mixed couples, second- and third-generation immigrants or immigrants from ethnically mixed areas. Due to the free mobility within the EU, the group of Hungarians living in Austria may also include commuters, part-time migrants or unregistered residents from Hungary and other Hungarian-speaking areas such as southern Slovakia.

Hungarians are officially recognized as an ethnic minority in Austria. However, there is no special legislation concerning the Hungarian minority outside Burgenland (that is, for at least three fourths of all Hungarians in Austria!); in Burgenland, there is a minority school law to guarantee bilingual tuition for the children of the Hungarian and Croatian minorities (LEPP 2008: 33-34, Brenner 2008, with further source references). The general visibility and media presence of Hungarian in Austria is rather weak; the national broadcasting company ORF offers a few programmes and 
news service in Hungarian, other Hungarian-language media, maintained by diverse Hungarian organizations, are few and of restricted coverage. Generally, very few Austrians acquire a working command of Hungarian, and the traditional idea of Hungarian as a language "impossible to learn" is still quite wide-spread. Yet, there has been some increase in the practical and financial importance of Hungarian; of the Austrian enterprises in Hungary, 50\% come from Burgenland and profit from the accessibility of Hungarian-speaking staff (LEPP 2008: 5).

\subsection{Teaching and studying Hungarian in Austria}

As mentioned above, the Austrian school system treats Hungarian on a par with any other non-national language - that is, allows for the teaching of Hungarian as a foreign language or, to Hungarian-speaking children, as an optional subject, provided that a sufficient number of children to start a group can be found. However, schools are not explicitly obliged to offer native-language instruction in a language other than German, and groups of children participating in this teaching are probably both few and small. According to the lists published yearly by the Ministry of Education, in the school year 2007/2008 Hungarian mother tongue was taught in altogether 13 schools in Austria outside Burgenland. ${ }^{1}$

In Vienna, there is also a "Hungarian School" (Mentsik 2008), founded by the Central Council of Hungarian Organizations in Austria and co-supported by the Austrian state - yet not officially part of the Austrian school system. The school offers Hungarian language lessons on a weekly basis for children and adolescents; the number of the pupils is constantly growing and has already reached 140. Despite the general positive trend, this is not very much in relation to the absolute numbers of Hungarian-origin population in Vienna.

Hungarian teaching for non-Hungarian children and youth is sporadically offered as well. In 2003, the project USIS (Ungarische Sprache in Schulen) was launched with the official support of the province of Lower Austria, and Hungarian teaching groups were

1 List published at http://www.bmukk.gv.at/medienpool/14006/schulen mutterspr_unterr.pdf, accessed 23 May 2009. 
initiated in numerous Lower Austrian schools. This project, however, is not directly connected with heritage language maintenance but rather with EU regional policies.

The only exception to the general Austrian model is the province of Burgenland, with its minority school law which should guarantee the use of Hungarian in the education system. Here, however, due to the rapid assimilation of the Hungarian minority during the 20th century, the number of school children who really speak Hungarian is so small that no exclusively Hungarian-medium tuition can be offered. In principle, children of the Hungarian minority in Burgenland (unless their parents explicitly oppose it) are enlisted in "bilingual" school curricula, but these groups are typically very heterogeneous (Pathy 2007) and Hungarian is in fact often taught like a foreign language (Brenner 2008).

Hungarian studies at university level are only offered at the Department of Finno-Ugrian Studies of the University of Vienna. (Hungarian translators and interpreters are educated at the universities of Vienna and Graz; Hungarian language courses are also offered at other universities.) For students of the Vienna department, there are two curricula with a Hungarian orientation: either a BA in Hungarian studies, optionally followed by an MA in Hungarian studies (= Hungarian literature and culture) or Finno-Ugrian languages, or a curriculum qualifying teachers of Hungarian for secondary schools (Lehramt Ungarisch). The latter is the only one of its kind outside the Hungarian language area proper.

\subsection{Case study: Hungarian heritage-language students in Vienna}

In this paper, we use the case of Hungarian heritage-language students at the Vienna Department of Finno-Ugrian studies to illustrate certain central questions of teaching a heritage language to heterogeneous student groups. The material stems from Márta Csire's observations and analyses; a part of these questions has already been dealt with in Csire (2008). We will proceed to the general problems of "multilingual" students in the educational system and finally plead for a more differentiated view on multilingualism.

As students cannot be expected to have learnt Hungarian in the Austrian school system, no previous knowledge of Hungarian is required. This means that a great part of the instruction in Hungarian 
studies at the University of Vienna consists of Hungarian language courses. The BA students of Hungarian studies who already have a good command of Hungarian can be exempted from the language courses if they pass the department's own language exam. For Lehramt students there is no option of this kind, and even fluent speakers of Hungarian are expected to participate in the language courses. This means that the students of Hungarian at the Vienna department cover the broadest possible spectrum of language knowledge. Some are first-generation immigrants educated in Hungarian-medium schools, some have grown up in Austria in Hungarian-speaking or bilingual families with very diverse patterns of Hungarian language use, and some come from monolingual German-speaking (or other) families without any previous exposure to the Hungarian language. The students who have grown up in Hungarian or bilingual families in Austria represent the whole continuum from relatively balanced bilingualism to "latent speakerhood" (Basham and Fathman 2008).

This paper departs from the questions arising in connection with those "bilingual" students for whom Hungarian can be called a heritage language (Herkunftssprache, származásnyelv). The concept of heritage language has in the last few years mostly been used in connection with linguistic minorities. The term heritage(-language) student is also a fairly new concept in language pedagogy; in this case we will, following Valdès (2005), use it for the various types of students in whose family background the Hungarian language is or was spoken. These students do not belong to a single homogeneous speaker community of Austrian Hungarians (such a community, as mentioned above, does not exist). Nevertheless, there are certain features characteristic of most of these students (Csire 2008: 141-142):

- They have learnt Hungarian as a spoken language at home, mostly already in their early childhood and simultaneously with German.

- They speak Hungarian almost exclusively with family members and relatives.

- They have been educated in German-medium Austrian schools. At school, they have also learnt other major European languages such as English but not received any tuition in Hungarian.

- In most domains of language use, German is clearly their dominant language. They often have a subjective feeling of "not knowing Hungarian well enough", and typically they have problems in reading and writing Hungarian. 
- Their Hungarian is based on one or more dialectal/colloquial varieties (as spoken in Hungary or other Hungarian-speaking areas), and they are not always aware of the fact that the dialectal features they use are not accepted in the standard language.

\section{The language competence of heritage-language students as a challenge for the teacher}

As noted before, the Hungarian heritage-language students in Vienna have acquired Hungarian as a spoken language in their childhood families. For most of them, the university studies are the first occasion where they are confronted with institutionalized teaching of Hungarian. Hungarian thus becomes a target language, which implies an essential change of perspective on language learning. At the same time, most of these students cannot precisely define what and how they would like to learn - usually, they mention as their motivation a vague wish "to learn Hungarian better". In fact, they do not recognize the difference between language learning in an institutional context (at school) and natural language acquisition in childhood. They lack the language awareness which would help them measure their language competence and, in general, consciously reflect on linguistic phenomena of any kind.

In order to really develop their language competence, the students would need a certain amount of language awareness to help them analyse, distinguish and understand language structures. The concept of language awareness was originally used in connection with first-language teaching, but it is now spreading to the terminology of second-language teaching as well. There have been various attempts to define language awareness on the basis of metalinguistic abilities (cf., e.g., McCarthy 1997); for the time being, we could start with a working definition of "awareness of language as a structured phenomenon and an ability to reflect on the structures of language". As our heritage-language students often lack this ability to reflect on language structures, they are unable to define the goals of their learning process and to develop a learning strategy which would support the development of their linguistic abilities.

In what follows, we will concisely present some features of the language competence of our Hungarian heritage-language stu- 
dents, sorted by the levels of language structure (also relevant for the methodology of language teaching). (For more examples see also Csire 2008.)

\section{Phonology}

Unlike German, Hungarian systematically distinguishes between short and long vowels and consonants, and the quantity opposition is in principle independent of word structure or stress (cf. bor 'wine' - bór 'borium', szeretem 'I love (him/her/it)' szerettem 'I loved'). The heritage-language students often fail to see these differences, even in cases where differences in vowel quantity are also accompanied by differences in vowel quality (they can confuse short $a[p]$ with long á [a:], short $e[\varepsilon]$ with long $e ́[\mathrm{e}:])$. Differences in vowel height can also be ignored ( $o$ instead of $a$ ), even in cases where the vowels belong to a suffix where they never vary and could be memorized as part of the suffix (e.g. †hall-ott-om ${ }^{2}$ instead of hall-ott-am [hear-PST-1SG] 'I heard'). ${ }^{3}$

\section{Morphology}

Due to a lack of morphological awareness, the students often cannot analyse word forms in terms of stems and suffixes. Not only morpheme boundaries but even word boundaries can be difficult to recognize, so that separate words are written together or parts of compound words apart.

The students cannot identify morphological categories, not even nouns and verbs. This may lead to confusing the similarsounding suffixes of the accusative case $(-(V) t)$ and the past tense $(-(V) t t): \dagger$ dolgozatott instead of dolgozatot 'thesis-ACC', †hozot instead of hozott 's/he brought'. They obviously do not consciously memorize the orthographic and phonetic forms of individual suffixes (for instance: that the terminative case ending is always - $i g$ ),

2 In order to avoid over-exploitation of the asterisk, we use the dagger $(\dagger)$ for the non-standard forms produced by the heritage-language students.

3 The 1SG suffix for past tense verb forms (in back-vowel words) is invariably am. However, the same (object-conjugation) suffix in the present tense has an $o$ (hall-om 'I hear (it)') and the similar-looking and etymologically cognate 1SG possessive suffix has two back-vowel variants (cf. ház-am 'my house' lány-om 'my daughter') - or, in an alternative interpretation, comes with two different linking vowels. 
which means an inconsistency and variation in writing: †félegyik instead of fél egyig [half one-TERM] 'until 12.30'. ${ }^{4}$

The orthography of Hungarian is largely morphematic and does not mark assimilation phenomena across morpheme boundaries. For instance, before the past tense suffix $t$ voiced stem-final consonants become voiceless, so that elkezd-t-em [begin-PST-1SG] 'I began' is pronounced [عlkestem]. The students, instead of writing words morpheme by morpheme, may simply rely on the usual phonological principles of Hungarian orthography and write †elkesztem.

The students may over-extend models of word-formation, forming ungrammatical derivatives by analogy or using a derivational suffix in an unappropriate context: instead of fel-friss-it 'freshen, fresh up' (verb formed from friss 'fresh' with the prefix fel- 'up' and the causative verb suffix -it), they may use †felfrissel, with another verb suffix.

\section{Syntax}

In many cases, deviances in syntax can be explained with interference from the dominant German language (this applies for many phenomena on other levels of language structure as well). Above all, the word order in heritage-language students' Hungarian often fails to follow the principles of Hungarian "discourse configurationality" (word order based on information structure) for instance, the focus position before the verb is ignored.

Characteristically, there are problems with the agreement between different constituents, for instance the agreement between subject and verb (verb in 3SG although the subject is in the plural) or object and verb (that is, the object conjugation or the marking of certain definite objects on the verb), as in example (1):

\section{(1) Majd a máig épülõ Sagrada Familia avagy Szent Család} Templomot $†$ megtekinthetïnk.

'Then, we can see the Sagrada Familia or Holy Family Church which is still under construction.'

Megtekinthetünk 'we can see' is a 1PL subject-conjugation form. If the object is a proper noun or carries the definite article

4 Note that egyik also exists; it is a derivative of egy ' 1 ' meaning 'one [of many], each'. 
$a(z)$ (both conditions are fulfilled here), the verb should be in object conjugation: megtekinthetjuik.

A typical example of German interference is also the unHungarian use of participle constructions. Unlike German, Hungarian only has one productive past tense and no analytic BE perfects for denoting an accomplished state. For transitive verbs, passive resultative past constructions of this type do appear (meg vannak ment-ve [PERF be-3PL rescue-PTC] 'they are/have been rescued'), and the students extend this model to intransitive verbs to create BE perfect constructions of the German type (cf. German sind weggegangen):

(3) A szülók †el $\begin{aligned} & \text { vannak } \\ & \text { the parents away are }\end{aligned}$
'The parents have gone away'

\section{Lexicon. Semantics}

As our heritage-language students only use Hungarian in a restricted set of domains, their vocabulary is correspondingly restricted. They know relatively few synonyms, they are not always aware of the stylistic connotations of lexical units, nor can they distinguish between different styles and modes of language use (colloquial, literary, dialectal, regional) but inadvertently mix elements of different stylistic shades within one text or spoken utterance. For instance, in their written essays they can use dialectal forms or words with a clearly regional flavour (örvendek 'I rejoice, I am happy', a characteristically Transilvanian word, instead of Standard Hungarian örülök).

The students may also memorize words in a misheard form: nonce words of this kind may be entrenched in their individual language use and they never notice that the word does not exist for the rest of the speaker community. Furthermore, they may confuse similar-sounding words. Due to the rich word formation system of Hungarian, there are many morpholexically and semantically related words which can be confused with each other. For instance, a student used the adjective idényi (a viable derivative of idény 'season') instead of idei 'this year's' (like idény, also ultimately derived from ido' 'time'). 


\section{Pragmatics}

Pragmatic competence means the ability to evaluate utterances from a pragmatic point of view, among other things, to decide whether they correspond to the context and the situation or whether they contain enough information to be understandable (Hug 2007: 24-25). For the heritage-language students, these conditions are not always fulfilled. Their utterances do not always comply to pragmatic expectations, even if they were grammatically correct. An example:

\section{(4) - Jó, akkor köszi a meghívást! ['OK then, thanks for the invitation!'] \\ - Nincs mit! Örülök már! ['Don’t mention it! I'm happy already!']}

Nincs mit (literally: 'There's nothing (to thank for)!') is not the idiomatic polite answer in this context. Örülök már ('I'm happy already', i.e. 'I'm looking forward to it') reflects the German Ich freue mich schon, but this is not the idiomatic way of expressing happy anticipation in Hungarian. (An idiomatic answer could be something like Szívesen! Akkor várlak. 'With pleasure! I'll be expecting you then.')

\section{Conclusion: The challenge to the teacher}

As shown by these examples, the heritage-language students have problems in their command of Hungarian on all levels of language structure, and these problems go back to insufficient metalinguistic awareness and to obvious foreign interference. Although the students often have the feeling that something is wrong or missing in their knowledge of Hungarian, they are unable to analyse and point out these problems themselves. In order to help them, the teacher should start by providing them with the same "tools" that a second-language learner normally acquires: some knowledge of formalized grammar rules, memorization of orthographic forms, inflectional paradigms etc. - and this should be done without destroying the students' confidence in the language knowledge they have already acquired.

Considering this, one could expect that integrated teaching groups like those at the Vienna department, including both heritage-language and second-language learners, could be a functioning solution. However, this integration does not always work - this problem will be dealt with in what follows. 


\section{Why "integration" of heterogeneous groups does not work}

Classroom lessons, however established as a form of language teaching, are "artificial situations" (Pauels 1995: 237). For those students who have only used the target language in natural contexts and in a certain fixed set of functions the situation is even more artificial and strange. The artificial situations created in a language class always have a certain distinct didactic goal, they serve the acquisition and entrenchment of certain linguistic structures and expressions which belong a certain level of language knowledge. The heritage-language students, although they often manage to react in the artificial situation and to solve the tasks, do not use those linguistic means (vocabulary, grammar) that the teacher wants to teach, to point out and to rehearse. Instead, their reactions and solutions are natural, spontaneous and instinctive also because they are not able to interpret the intentions of the teacher and produce the reactions the teacher is expecting. Regrettably, their fellow students who are learning Hungarian as a second language can seldom make use of heritage speakers' spontaneous reactions in their own learning process; in fact, they often fail to understand them.

Integrated teaching groups are also often expected to support intercultural learning and understanding. As part of the communicative competence, a language learner should acquire an ability to recognize cultural differences in both linguistic and non-linguistic behaviour and to reflect on them. (Krumm 1995: 156-157.) However, most of the Hungarian heritage-language students in Vienna have grown up in Austria. For them, knowledge of the Hungarian language is not necessarily connected to another culture; it could be stated that there is only one cultural behaviour underlying their both languages. For this reason, they cannot actively participate in the process of intercultural learning. On the contrary, it may be difficult for them to recognize that differences in language could be connected with differences in non-linguistic forms of behaviour - previously, they have either ignored these differences or believed they master them already.

To sum up: integrated teaching groups do not work, because it is almost impossible to synchronize and reconcile the different learning goals, strategies, linguistic and extralinguistic competences of different learner groups. 


\section{Conclusions}

In this paper, we have attempted to outline some central problems illustrated by the case of Hungarian heritage-language students in Austria. First of all, heritage-language university students, despite formal language instruction in secondary school, still lack the metalinguistic awareness which they would need in order to evaluate their command of their heritage language, in order to set their learning goals and to develop their own learning strategies. Whatever language awareness is developed in school education seems to be highly language-specific or strategy-specific and cannot be automatically transposed to the learning of further languages. For instance, having studied English or French does not seem to help Austrian-Hungarian students to analyse their grammatical intuitions about Hungarian.

Secondly, heritage-language students form a group of their own, and their learning problems differ from both those of first language learners and those of second language learners. Unlike second language learners, they can use their target language already at the very beginning, and they do not see their language learning as part of a cultural border-crossing process ("acculturation" or "intercultural learning"). This means that teaching strategies which emphasize aspects of interculturality and cultural differences as well as teaching methods based on routines of oral communication might be less well suited for the expectations, motivations and learning strategies of heritage-language students.

On the other hand, the main problems in the formal, institutionalized teaching of a heritage language also differ from those in the formal teaching of a first language. Heritage-language students are far less confident about their own language knowledge and often suffer from a subjective feeling of insecurity. The problems adult heritage-language learners have with reading and writing are untypical of learners of their age and may be felt as humiliating and de-motivating. Institutional teaching of the heritage language as a literary language confronts the students with a broader spectrum of domains and styles than they have previously known and with challenges they have not expected.

All these problems imply that specific teaching strategies and methods for heritage-language learners should be developed. This question is probably much more general than we have been able to show and pertains to a vast number of minorities all over the world. 
Modern minorities in Europe do not live in clearly segmentable, geographically isolated and ethnically "pure" monolingual sub-communities. Yet, although all linguists working on these questions readily admit that multilingualism and language contact are extremely complicated concepts, official language policies in many countries still reflect the national-romantic nation-state ideal, "projecting an anachronistic, rural idea of ethnic purity onto their mixed urban populations" (Barbour 2000: 6). Introducing modern ideas of linguistic human rights into this conceptual world means simply multiplying the idealized purity and not acknowledging the central fact that "speaking a language" is not a simple yes/no question and that "ethnic speakers" of a minority language may represent very different grades of language knowledge which require more differentiated language planning and educational strategies. The latter may imply giving up the commensurability of the command of a heritage language with the "first language" in the usual European sense of the word.

In the words of Anna Kollath (2008: 191-192; translation JL), an expert on the Hungarian minority in Slovenia, we need "a corresponding bilingual perspective on language. By this, I mean that first language acquisition of minority children requires other methods than in Hungary [in the "motherland"]. One cannot emphasize too often that the command of the monolingual mothertongue variety in a context of bilingualism is an irrealistic requirement. It will not only make the life of individual people more difficult, it will also - especially in case of a language shift situation endanger the existence of the whole community."

\section{Address:}

Marta Csire and Johanna Laakso

Abteilung Finno-Ugristik / EVSL

Campus AAKH Spitalgasse 2-4 Hof 7

A-1090 Wien

Austria

E-mail:marta.csire@univie.ac.at

E-mail: johanna.laakso@univie.ac.at 


\section{References}

Barbour, Stephen (2000) "Nationalism, language, Europe”. In Stephen Barbour and Cathie Carmichael, eds. Language and nationalism in Europe, 1-17. Oxford: Oxford University Press.

Basham, Charlotte and Ann K. Fathman (2008) "The latent speaker: attaining adult fluency in an endangered language". International Journal of Bilingual Education and Bilingualism 11, 5, 577-597.

Brenner, Edina (2008) “Ungarischunterricht im Burgenland”. In Johanna Laakso, ed. Ungarischunterricht in Österreich = Teaching Hungarian in Austria, 128-138. (Finno-Ugrian Studies in Austria, 6.) Wien: LIT Verlag.

Csire, Márta (2008) „Ungarisch-deutsche Zweisprachige im Sprachunterricht: Über die Problematik einer speziellen Zielgruppe“. - In Johanna Laakso,ed. Ungarischunterricht in Österreich = Teaching Hungarian in Austria, 139-153. (Finno-Ugrian Studies in Austria, 6.) Wien: LIT Verlag.

Deák Ernő [s.a.] Az Ausztriai magyarok és a központi szövetség. [The Hungarians in Austria and the Central Council of Austrian Hungarians.] http:// www.geocities.com/ihunsor/szorvanymagyarsag/azausztriaimagyarok.htm, accessed 23 May 2009.

Hug, Michael (2007) "Sprachbewusstheit/Sprachbewusstsein - the state of the art”. In Michael Hug and Gesa Siebert-Ott, Hrsg. Sprachbewusstheit und Mehrsprachigkeit, 10-31. (Diskussionsforum Deutsch, 26.) Baltmannsweiler: Schneider Verlag Hohengehren GmbH..

Jelentés 2006 = "2006. évi jelentés az ausztriai magyarok helyzetéröl". [Report of the situation of Hungarians in Austria 2006.] http://www.hhrf.org/htmh/ ?menuid=060202, accessed 30 March 2009.

Kolláth, Anna (2008) "Die Problematik des Ungarischunterrichts in Slowenien". In Johanna Laakso, ed. Ungarischunterricht in Österreich = Teaching Hungarian in Austria, 179-199. (Finno-Ugrian Studies in Austria, 6.) Wien: LIT Verlag.

Krumm, Hans-Jürgen (1995) “Interkulturelles Lernen und interkulturelle Kommunikation". In Karl-Richard Bausch and Herbert Christ and Hans-Jürgen Krumm, Hrsg. Handbuch Fremdsprachenunterricht, 156-161. Tübingen und Basel: Francke Verlag.

LEPP 2008 = Language education policy profile Austria . Language Policy Division (Strasbourg), Ministry of Education, the Arts and Culture and Ministry of Science and Research (Vienna), 2008. (http://www.coe.int/T/ DG4/Linguistic/Profils1_EN.asp, accessed 30 March 2009.)

McCarthy, John (1997) "Towards a conceptual framework for implementing a cross-curricular approach to language awareness in the school curriculum". Language Awareness 6, 208-220. 
Mentsik Szilvia (2008) "Bemutatkozik a Bécsi Magyar Iskola”. Anyanyelvpedagógia 3-4. (Online: http://www.anyanyelv-pedagogia.hu/ cikkek.php?id=85, accessed 23 May 2009.)

Pathy, Lívia (2007) "Fremdsprache oder Muttersprache? Ungarischunterricht in inhomogenen Lerngruppen im Burgenland". WEBFU 1/2007 (http:// webfu.univie.ac.at/).

Pauels, Wolfgang (1995) “Kommunikative Übungen”. In Karl-Richard Bausch, Herbert Christ and Hans-Jürgen Krumm, Hrsg. Handbuch Fremdsprachenunterricht, 236-238. Tübingen und Basel: Francke Verlag.

Valdés, Guadalupe (2005) "Bilingualism, heritage language learners, and SLA research: opportunities lost or seized?". The Modern Language Journal $89,410-426$.

Kokkuvõte. Marta Csire ja Johanna Laakso: Pärandkeele kui võõrkeele õpetamine: kakskeelsus ja vähemuskeelte õpetamise küsimusi Austrias. Kuigi ungarlased on Austrias ametlikult tunnustatud etniline vähemus, pööratakse üllatavalt vähe tähelepanu spetsiifilistele probleemidele ungari keele kui pärandkeele õpetamisele. Artikkel keskendub ungari keelt pärandkeelena rääkivate tudengite olukorrale: nimetatud üliõpilased õpivad koos saksa keelt rääkivate tudengitega Viini Ülikoolis ungari keelt ühe osana õppekavast. Need tudengid on õppinud peresiseselt erinevaid ungari kõnekeele variante, kuid enamasti pole nad ametlikku kirjakeelt õppinud. See toob kaasa vead, mis tulenevad sageli puudulikust keeleteadlikkusest: pärandkeelt õppivad tudengid ei oska analüüsima oma grammatilist intuitsiooni. On ilmne, et pärandkeelt õppivatel üliõpilastel ei ole kasu traditsioonilistest teise keele õpetamise meetoditest ja materjalidest. Veelgi enam, erinevad õpperühmad pigem tekitavad kui lahendavad probleeme. Need küsimused, mis on tõenäoliselt väga tõsised aina suurenevate mitmekeelsete rühmade jaoks paljudes maades, nõuavad spetsiifilisemaid lähenemisviise keeleplaneerimise haridusstrateegiate osas.

Märksõnad: pärandkeel, ungari keel, akadeemilised õppijad, keeleteadlikkus 
